\title{
COMMENTS
}

\section{Hybrid Instruments and the Debt-Equity Distinction in Corporate Taxation}

Debt and equity are treated differently for many purposes in federal tax law. The most important difference is that payments made on debt may be deducted in computing a corporation's taxable income, ${ }^{1}$ while payments made on equity may not. Although this distinction is well-settled, it has little theoretical basis ${ }^{2}$ and is not clearly drawn in the tax law. ${ }^{3}$ As a result, there has for a long time been confusion over how to classify, for tax purposes, instruments that do not closely resemble "ordinary" debt or "ordinary" equity. ${ }^{4}$

Until 1969, the Internal Revenue Code (the Code) provided no guidance in defining "debt" or "equity." In the Tax Reform Act of $1969,{ }^{6}$ Congress added section $385^{7}$ to the Code in an attempt to deal with this problem. Rather than provide a statutory definition of debt and equity, however, Congress simply delegated to the Secretary of the Treasury the power to issue regulations that would "determine whether an interest in a corporation is to be treated . . . as stock or indebtedness." In 1980, the Treasury Department finally proposed regulations under section 385 that would have provided a framework for classifying debt and equity for federal tax purposes. ${ }^{9}$ The proposed regulations included a "test" enabling

1 I.R.C. § 163(a) (1982).

${ }^{2}$ See infra notes 70-96 and accompanying text.

${ }^{3}$ See infra notes 21-23 and accompanying text.

- See infra notes 21-45 and accompanying text.

- See Plumb, The Federal Income Tax Significance of Corporate Debt: A Critical Analysis and a Proposal, 26 TAX L. REv. 369, 369-70 (1971).

${ }^{\circ}$ Pub. L. No. 91-172, 83 Stat. 487 (1969) (codified in scattered sections of the I.R.C. (1982)).

7 Id. $\S 415(\mathrm{a}), 83$ Stat. 613 (codified at I.R.C. $\S 385$ (1982)).

s I.R.C. $\S 385(a)$ (1982). For a discussion of the legislative role in tax policy, see Note, Toward New Modes of Tax Decisionmaking-The Debt-Equity Imbroglio and Dislocations in Tax Lawmaking Responsibility, 83 HARv. L. REv. 1695 (1970).

${ }^{9}$ Proposed Treas. Reg. $\S \S 1.385-1$ to .385-12, 45 Fed. Reg. 18,957 (1980) (proposed Mar. 
corporations to issue hybrid securities ${ }^{10}$ that would qualify as debt, despite their widely recognized equity status. Perceived as a failure, ${ }^{11}$ these regulations were withdrawn in $1983 .{ }^{12}$

An analysis of the debt-equity classification problem demonstrates that any attempt to draw a principled distinction between the two will be fruitless. At least in the absence of the special evidentiary problems presented by small and closely held corporations, ${ }^{13}$ no tax-policy rationale can justify the time and effort spent in distinguishing debt from equity. A rule allowing debt treatment for only the most debt-like instruments, thus eliminating debt treatment for hybrid instruments, would reduce complexity and confusion and would sacrifice few, if any, of the goals underlying the federal corporate tax scheme.

Part I of this comment examines the origins and consequences of the debt-equity distinction and describes the Treasury's attempts to police the distinction. The discussion in Part I shows that attempts by the courts and the Treasury to enforce the debtequity distinction have failed because the traditional rationale for the distinction is both impracticable and based upon factually incorrect premises. Part II examines the distinction from the viewpoint of modern financial theory and shows that no sound theoretical basis now exists for distinguishing between debt and equity; any attempt, therefore, to classify hybrid instruments in a principled fashion is likely to be arbitrary in practice and will encourage wasteful efforts by tax planners to create instruments that take advantage of whatever line is drawn. Part III proposes a test to govern the classification of debt and equity for instruments issued in arm's-length transactions by large, publicly held corporations. Under this test, only those instruments that closely resemble straight debt would be accorded debt treatment under the

24, 1980), revised, 45 Fed. Reg. 18,957 (1980), revised and reproposed as Proposed Treas. Reg. $\S \S 1.385-0$ to .385-8, 47 Fed. Reg. 164 (1982), withdrawn, 48 Fed. Reg. 31,053-54 (1983) [hereinafter cited as Proposed Regulations].

10 A hybrid security is one that combines features of ordinary debt and ordinary equity. Any security that normally provides some guaranteed return to the investor, but at the same time may pay out more or less depending on the corporation's fortunes, is a hybrid security. The term also carries connotations of the new or unusual. Thus, while preferred stock is technically a hybrid security, it is not generally classified as such because of its long presence in the market. See generally H. HENN \& J. AleXANDER, LAws of CoRPorations 409-13 (3d ed. 1983).

11 The failure of the Treasury's test to provide a satisfactory solution is explained infra notes $49-67$ and accompanying text.

1248 Fed. Reg. 31,053-54 (1983); cf. Rev. Rul. 83-98, 1983-2 C.B. 40 (disallowing debt classification for an instrument that would have qualified under the Proposed Regulations).

${ }^{13}$ See infra notes 116-17 and accompanying text. 
Code-all hybrid instruments would be treated as equity unless they were sold as packages of separately salable debt and equity instruments. As this comment will show, such an approach is the only satisfactory way to handle the debt-equity classification problem, at least in the context of arm's-length transactions.

\section{Attempts to Distinguish Debt and Equity}

Perhaps the most important distinction between debt and equity under the tax laws is that a corporation may deduct interest paid to holders of debt, ${ }^{14}$ while dividends to stockholders must be paid out of after-tax income. ${ }^{15}$ Since corporations prefer to deduct as much as possible from gross income in order to lessen their taxes, it has long been popular to fashion instruments that are neither obviously debt nor obviously equity, in the hope that the Internal Revenue Service (the Service) will allow the deduction of payments made pursuant to them. ${ }^{16}$ Corporations thus hope to obtain the tax benefits of debt, while avoiding the fixed-payment obligations that normally accompany it. ${ }^{12}$

14 I.R.C. \& 163(a) (1982).

${ }^{15}$ But cf. id. $\S 247$ (providing a limited exception for certain public utility stock). For an illustration of the financial impact of the differential tax treatment of debt and equity, see Kaplan \& Yoder, New Variations on an Old Enigma: The Treasury Department's New Debt-Equity Regulations, 1981 U. ILL. L. REv. 567, 572.

Another difference in tax consequences arises from the treatment of worthless obligations. Worthless securities give rise to a capital loss, I.R.C. $\$ 165(\mathrm{~g})$ (1982), but a bad debt that does not qualify as a security gives rise to an ordinary loss, $i d$. $\S 166$. In addition, the nonrecognition provision of section 351 turns on what sort of obligation the corporation issues in exchange for property contributed. See id. $\S 351$. Furthermore, the Code's treatment of corporate reorganizations turns on the nature of the interest assumed by the firm's shareholders. See, e.g., LeTulle v. Scofield, 308 U.S. 415, 420-22 (1940); see also John A. Nelson Co. v. Helvering, 296 U.S. 374, 384-85 (1935). Similarly, the Code's treatment of distributions of a corporation's own obligations to existing shareholders differs depending on the nature of the obligations. See I.R.C. $\$ \S 301,305,306$ (1982). For a discussion of some of these differences, see Fin Hay Realty Co. v. United States, 398 F.2d 694, 696-99 (3d Cir. 1968). See generally B. Bitrker \& J. Eustice, Federal Income Taxation of Corporations AND SHAREHOLDERS If $4.01-.12$ (4th ed. $1979 \&$ Supp. 1984).

${ }_{16}$ See B. BiTTKER \& J. Eustice, supra note 15, at โा 4.01-.02.

17 This may suggest that the fixed obligations a corporation assumes when it issues an instrument might be used to distinguish debt and equity. That is, the more of its earnings a corporation commits itself to pay out to various claimants, the more debt it will have. Since fixed claims are associated with debt by definition, however, such a distinction is tautological. Distinguishing debt and equity in this way may be useful to the financial taxonomist, but it provides little help for one interested in designing a better tax system.

This method of distinguishing debt and equity also suffers from an improper focus on the corporate entity, neglecting the point of view of the corporation's investors. All claimants to the corporation's earnings value their claims only to the extent that they will be able, eventually, to withdraw funds from the corporation. Equity claimants differ from debt claimants in this respect only in that they do not know in advance exactly when and how 
If the Service always allowed these hybrid instruments to be treated as debt for tax purposes, most distributions eventually would be made pursuant to these instruments, and the use of "ordinary" equity would decline sharply. As a result, the corporate income tax ${ }^{18}$ would be reduced to little more than a tax on retained earnings. ${ }^{18}$ Those who oppose the corporate income tax ${ }^{20}$ might welcome this result. Assuming, however, that a corporate income tax is desirable, the virtual abandonment of its enforcement is clearly not acceptable. It is therefore necessary to undertake the difficult task of drawing a clear line between debt and equity.

\section{A. Judge-Made Distinctions Between Debt and Equity}

The now classic distinction between shareholder and creditor, and therefore between dividends and interest, was drawn by the Second Circuit in Commissioner v. O.P.P. Holding Corp. ${ }^{21}$ There the court stated that the "vital difference" between the shareholder and the creditor is that

[t]he shareholder is an adventurer in the corporate business; he takes the risk, and profits from success. The creditor, in compensation for not sharing the profits, is to be paid independently of the risk of success, and gets a right to dip into

much they can expect to be able to withdraw funds from the corporation.

Furthermore, a seeming corollary of any distinction based on the proportion of fixed obligations assumed under an instrument is that corporations that have more financial freedom should be taxed more heavily, and conversely, that it is unfair if they are not so taxed. This argument, however, ignores the fact that the corporation is no more than a mechanism for focusing the interests of a collection of individuals. See Easterbrook \& Fischel, Limited Liability and the Corporation, 52 U. CHI. L. REv. 89, 89 (1985) ("corporation . . . . no more than a name for a complex set of contracts"). What may appear to be more or less onerous for the corporation may not be so to the individuals who are behind it; consequently, it is not necessarily fairer to tax more heavily corporations that are free of fixed obligations. Instead, the tax system should look into the underlying nature of those obligations to distinguish debt and equity. This will be explored more fully infra notes 24-68 and accompanying text.

18 I.R.C. $\S 11$ (1982) (the top corporate rate is $46 \%$ ).

19 Depending on where the Service drew the line, the corporate income tax would more or less be eliminated. As corporations issued hybrid securities (qualifying as debt) instead of the equity they would have issued absent the tax, receipts under the corporate income tax would be reduced from what they would have been if the securities were treated as equity. That is, by changing the form of the instruments, taxpayers would, to some extent, be permitted to avoid the tax. Cf. H.R. REP. No. 1337, 83d Cong., 2d Sess. 39 (1954) (recognizing that tax consequences of essentially identical transactions can often be widely disparate); Isenbergh, Musings on Form and Substance in Taxation (Book Review), 49 U. CHI. L. Rev. 859 (1982) (same).

${ }^{20}$ See infra note 101.

2176 F.2d 11 (2d Cir. 1935). 


\section{the capital when the payment date arrives. ${ }^{22}$}

This view is based on the notion that, because the shareholder benefits from investing through the corporate form, he should not be allowed to extract his profits until after they have been subjected to the corporate income tax. Conversely, the cost of borrowing money (interest) is seen as an ordinary and necessary cost of doing business that should no more have to be met out of after-tax dollars than should workers' salaries or the cost of raw materials. ${ }^{23}$

Although the distinction drawn in O.P.P. Holding has an intuitive appeal, the court's reasoning does not successfully draw a principled distinction. The distinction fails because the difference between creditor and shareholder is, in an important sense, one of degree only. Both shareholders and creditors contribute capital to the corporation in the expectation that the corporation will be able to use this capital productively and return it to them along with a

22 Id. at 12.

${ }^{23}$ Congress itself has never provided a better explanation for the disparate treatment of debt and equity. The legislative history of section 385-Congress's first attempt to clarify the manner in which the distinction should be drawn-is silent both as to the reason for the distinction and as to the theory underlying the list of factors in section 385 for distinguishing debt and equity. See S. REP. No. 552, 91st Cong., 1st Sess. 137-44 (1969), reprinted in 1969 U.S. Code Cong. \& AD. NEws 2027, 2169-76. Indeed, section 385 was not enacted specifically for the purpose of clarifying the debt-equity distinction. Rather, its purpose was to give the Treasury greater authority to deal with the problem of the increasing use of debt in corporate mergers and acquisitions. See id. at 137-39, 1969 U.S. CoDE Cong. \& AD. News at 2169-71.

The debt-equity distinction has always been an implicit one, required by the fact that interest payments are deductible in computing corporate income. I.R.C. $\S 163(\mathrm{a})$ (1982) ("There shall be allowed as a deduction all interest paid or accrued . . . on indebtedness."). Predecessors of section 163(a) can be traced back to 1864, see Act of June 30, 1864, ch. 173, $\S 117,13$ Stat. 223, 281-82, although Congress has provided little explanation for the distinction since then. "[The 1864] Congress evidently reasoned that a business must pay the costs of the factors of production-land, labor and capital. Therefore, it permitted the deduction of rent, wages and business interest . . . Asimow, Principal and Prepaid Interest, 16 UCLA L. REv. 36, 62 (1968). Apparently, the idea that interest payments are deductible as an ordinary business expense is so intuitively appealing that Congress has thought it unnecessary to explain section 163(a) or its predecessors. Indeed, if one considers a typical small business that simply borrows money from the bank to finance its operations, it seems obvious that the cost of that capital is a business expense and therefore should be deductible. When one considers that equity is simply another source of capital, however, this basis for the distinction begins to fall apart. See infra note 24 and accompanying text; infra text accompanying note 71 . Accordingly, the traditional rationale provides little guidance in classifying sophisticated instruments or transactions that are neither clearly debt nor clearly equity. For discussions of the history of the interest deduction and of the very meager legislative history of section 163(a) and its predecessors, see Asimow, supra, at 61-64; Berger, Simple Interest and Complex Taxes, 81 Colum. L. Rev. 217, 217-39 (1981); Warren, The Corporate Interest Deduction: A Policy Evaluation, 83 Yale L.J. 1585, 1585-86 (1974). 
share of the resulting gain..$^{24}$ Furthermore, it is inaccurate to characterize all shareholders as necessarily bearing more risk than all creditors. The degree of risk to which an investor is exposed, and the potential payoff that he can expect, can vary more between the bond of one company and the bond of another than between the debt and stock of the same company. For example, a bond may carry such a high risk of default that its nominal return is higher than any conceivable return on a much less risky blue-chip share. Thus, the holder of the risky bond may be more "an adventurer in the corporate business"25 than is the holder of the blue-chip share. And due to the bond's high risk, only a small part of its nominal yield will be attributable to the pure cost of capital. The margin over this risk-free rate of interest, if it is in fact realized, will represent entrepreneurial gain. ${ }^{26}$ By contrast, most of the return on a

24 The bondholder is, of course, entitled to a fixed amount of the gain. If there is no gain he is still "entitled" to the same fixed amount, but in practice he can only cause the borrower to declare bankruptcy and then himself become the owner of its assets. 11 U.S.C. ch. $3, \S 303$ (1982); id. ch. 7; id. ch. 11. Presumably these assets will not be sufficient to satisfy his claims. If they were, the company's owners would have partially liquidated the company themselves, satisfied the creditor, and retained the balance of the corporation's assets for themselves. (Of course, the owners would be entitled to this balance after the bankruptcy court has satisfied all the creditors in any case, but the expense and complicated nature of the bankruptcy process tends to reduce the amount available to the owners and is best avoided.) The creditor thus hopes to recoup an amount somewhere between zero and the promised payment. The owner is in the same position, except that, because his return is not limited contractually, the probability distribution governing his return has no fixed upper bound. This, however, is more a theoretical than a practical difference.

The discussion above should not be taken to mean that there are not many important taxonomic distinctions that can be drawn between "creditors" and "owners." The point, rather, is that these distinctions are merely descriptive. The difference between the taxonomic and the substantive approach to distinguishing debt and equity is well captured in the following passage:

Instead of thinking of shareholders as joint owners, we can think of them as investors, like bondholders, except that the stockholders are more optimistic than bondholders about the enterprise prospects. ... [S] [Sareholders prefer to invest funds with a greater realizable return if the firm prospers ....

…

If we treat bondholders, preferred and convertible preferred stockholders, and common stockholders and warrant holders as simply different classes of investors-differing not only in their risk averseness but in their beliefs about the probability distribution of the firm's future earnings, why should stockholders be regarded as 'owners' in any sense distinct from the other financial investors?

Alchian \& Demsetz, Production, Information Costs, and Economic Organization, 62 Ам. Econ. Rev. 777, 789 n.14 (1972) (emphasis in original); see infra notes 70-96 and accompanying text.

2s O.P.P. Holding Corp., 76 F.2d at 12.

${ }^{28}$ It should be emphasized that entrepreneurial gain is nothing more than compensation for the risk of loss inherent in an investment with a high volatility. An entrepreneur is one who "organizes and manages a business undertaking, assuming the risk for the sake of 
blue-chip stock is merely the required return on capital; little, if any, represents a return of entrepreneurial gain. ${ }^{27}$

The O.P.P. Holding court was probably influenced by the original justification for and explanation of the corporate income tax offered by the Supreme Court in Flint $v$. Stone Tracy Co. ${ }^{28} \mathrm{In}$ Flint, the Court upheld the constitutionality of a tax that effectively reached corporate income ${ }^{29}$ despite its earlier ruling that an income tax was unconstitutional unless apportioned among the states. ${ }^{30}$ The tax under review in Flint was not technically an income tax; rather it was a one-percent excise on corporations, to be measured by income. ${ }^{31}$ The Court found the tax to be constitu-

profit." Webster's New World Dictionary 467 (2d ed. 1976) (emphasis added); see also Black's Law Dictionary 478 (5th ed. 1979); $c f$. R. Brealey \& S. Myers, Principles of CoRPORATE FinaNCE 112-89 (1981) (discussing the function of risk in corporate finance). The entrepreneur's investment is volatile because he purchases an interest in the portion of the corporation's return that is the first to be eliminated if returns are less than expected, while he also captures all the greater-than-expected returns. On balance the entrepreneur will achieve a return equal to that expected from a less volatile investment, assuming he is risk neutral. Nevertheless, his nominal return will be greater to compensate for the greater risk of loss. If the investor is risk averse, he will demand compensation in the form of an even higher nominal return so that the expected return on his investment is higher than that on the less risky investment: the investor will demand a risk premium, which should not be confused with that portion of the nominal yield that represents entrepreneurial gain and only ensures that the expected return on the investment is equal to that on the less risky investment.

${ }^{27}$ See supra note 26. The same conceptual misunderstanding found in O.P.P. Holding can be seen in Commissioner v. Meridian \& Thirteenth Realty Co., 132 F.2d 182 (7th Cir. 1942). There the court said that the essential difference between a creditor and a shareholder is that the "latter intends to make an investment and takes the risks of the venture, while the former seeks a definite obligation, payable in any event." Id. at 186 . The bondholder, however, also "takes the risks of the venture." If the enterprise takes a turn for the worse and the shareholders' investments become worthless, any further losses will come out of the bondholder's investment. While the bondholder's investment will thus be forfeited only upon a more extreme contingency than will that of the shareholder, it is still an investment and still risky, though to a lesser degree than that of the shareholders of the same firm.

The argument that the distinction between owners and creditors is illusory is even stronger when one compares different firms. The bond of a new or struggling company may be at much greater risk than the shares of a well-established firm. See supra notes 24-27 and accompanying text.

${ }^{28} 220$ U.S. 107 (1911).

${ }^{29} \mathrm{Id}$. at 177.

${ }^{30}$ Pollock v. Farmers' Loan \& Trust Co., 158 U.S. 601, 619-37 (1895) (referring to U.S. Const. art. I, §§ 2, 9), overruled by U.S. ConsT. amend. XVI.

${ }^{31}$ Payne-Aldrich Tariff Act of 1909, ch. 6, $\S 38,36$ Stat. 11, 112-17, repealed by Act of Oct. 3, 1913, ch. 16, 38 Stat. 114, 201. In substance, if not in form, the tax reviewed in Flint was obviously an income tax:

In 1909, the pressure for an income tax culminated in a compromise with the addition of the Corporate Excise Tax of 1909 as an amendment to the Payme-Aldrich Tariff Bill and the adoption of a joint resolution by the Senate and House of Representatives 
tional because it was a "special excise tax with respect to the carrying on or doing business by [a] corporation. ... . [It was] a tax upon the doing of business with the advantages which inhere in the peculiarities of corporate . . . organization . . .."32 Although the sixteenth amendment granted Congress the power to tax income (presumably including corporate income) without apportionment, thus rendering Flint's reasoning unnecessary for constitutional purposes, the philosophical or policy reason developed in Flint is still cited in support of the corporate income tax. ${ }^{33}$

Unfortunately, the idea of taxing the corporation for the benefits it derives from doing business in the corporate form does not support a principled distinction between debt and equity: the reasoning in Flint provides no better understanding of the debt-equity distinction than does that in O.P.P. Holding. ${ }^{34}$ One could argue from Flint that because an entity's creditors are never

submitting the sixteenth amendment to the states for ratification.

J. Nowak, R. Rotunda \& J. Young, Constitutional Law 184 (1983) (emphasis added). Prior to the passage of the sixteenth amendment, U.S. CoNST. amend. XVI, in 1913, Congress was unable to enact an income tax without this sort of legislative prevarication. Compare Flint with Pollock v. Farmer's Loan \& Trust Co., 158 U.S. 601, 618-19, 637 (1895) (holding Income Tax Act of 1894 a direct tax and therefore unconstitutional because imposed without apportionment).

${ }^{32}$ Flint, 220 UI.S. at $\mathbf{1 4 5 - 4 6 .}$

${ }^{33}$ See, e.g., Plumb, supra note 5, at 623-24. While a theory of corporate taxation founded on a juristic conception of the corporation as a legal entity might be appealing to legal theorists, it is not clear what that theory has to do with the essential questions of taxation. Cf. Williams v. McGowan, 152 F.2d 570, 573 (2d Cir. 1945) (Frank, J., dissenting in part) (rejecting "animistic" view of fictitious entities).

A different and more obvious explanation of the corporate tax is the simple desire to raise money. Because all taxes share this rationale, however, this explanation provides no particular insight into the corporate tax. See Plumb, supra note 5, at 622-24 (noting that "fiscal expediency" as an explanation for taxation must be set aside).

A third rationale for the corporate income tax might be that it facilitates the breakup of large aggregations of wealth and encourages individual proprietors by giving them a competitive advantage. A full analysis of this argument is outside the scope of this comment. For a historical discussion of the Populist movement, which favored the corporate income tax for its supposed economic-leveling function, and the movement's role in the adoption of the sixteenth amendment, see Randolph Paul, Taxation in the United States chs. I-III (1954). As is the case with the other possible rationales for the corporate income tax, this explanation provides no assistance in understanding the debt-equity distinction.

st It may not seem reasonable to expect Flint, which does not deal with the debt-equity distinction, to offer clues to a solution of the problem. Nevertheless, a case dealing with the rationale for a corporate income tax should provide some insight into the problem of defining corporate income, and the debt-equity classification question is nothing more than a problem in the definition of corporate income. Cf. Henry Simons, Personal Income Taxation: The Definition of Income as a Problem of Fiscal Policy passim (1938) (what is deductible, e.g., interest payments, is not "income"; therefore, in deciding what is "debt" we are deciding what is "income"). Simons explains that this decision must be made with reference to the normative bases of taxation. See id. at 205-24. 
personally liable in bankruptcy, regardless of the form in which the entity does business, creditors do not benefit from lending to an enterprise doing business as a corporation. Owners, by contrast, benefit from using the corporate form because it provides them with the shield of limited liability, which is not automatically available when doing business in other forms. Therefore, one might conclude, it is legitimate to exempt from corporate taxation only distributions made to creditors. This argument ignores the fact that creditors as a class may benefit from the shareholders' limited liability as much as the shareholders themselves. Because limited liability shifts part of the risk of the venture to the lender, the interest rate on a loan, which in part reflects the possibility that the loan will not be repaid, will be increased to account for the fact that the borrower's owners are not personally liable on the loan..$^{36}$ Moreover, this arrangement is beneficial both because it tends to shift more of the risk onto those with the best information-gathering skills ${ }^{36}$ and because limited liability facilitates investment by risk-averse individuals. ${ }^{37}$ Thus, "the principle of limited liability in corporation law facilitates a form of transaction advantageous to both investors and creditors; in its absence the supply of investment and the demand for credit might be much smaller than they are."38 As a class, therefore, lenders benefit from having the opportunity to lend to enterprises whose owners enjoy the protection of

${ }^{33}$ See Posner, The Rights of Creditors of Affiliated Corporations, 43 U. ChI. L. REv. 499, 503 (1976).

${ }^{36}$ See id. at 501-02. For example, one would expect an individual shareholder in a large, publicly held corporation to be less expert at appraising the risk of default than a bank that lends money to the same corporation. See id. at 502 .

${ }^{37}$ See id. at 502 . This benefit is significant since most investors are risk averse. See id. at 502 \& n.9 (citing empirical evidence summarized in J. LoRIE \& M. HAMILTON, THE STOCK MARKET: THEORIES AND Evidence 198-227 (1973)).

3s Posner, supra note 35, at 503. The notion that only shareholders benefit from limited liability is untenable for yet another reason: any noncorporate borrower is free to negotiate a nonrecourse loan, and thus obtain the benefits of limited liability by private negotiation instead of incorporation. By the same token, a corporation's creditors can insist that the owners be personally liable on loans, thus contractually removing the shield of limited liability. In certain limited contexts, such negotiating may not be possible; for example, in nonconsensual cases involving the liability of corporate tortfeasors, no negotiation is possible and the corporation and its victim must abide by any supplied terms. See, e.g., Walkovszky v. Carlton, 18 N.Y.2d 414, 417-18, 223 N.E.2d 6, 7-8, 276 N.Y.S.2d 585, 587-88 (1966) (discussing corporate liability for judgments in tort against corporate owners of taxicabs involved in accidents with pedestrians). Where negotiation is possible, however, the "benefits" of doing business in the corporate form are merely the transaction costs saved in those cases where the parties prefer the supplied terms to any others. These savings are not enjoyed by owners alone: they facilitate contracting and thus benefit creditors as well as owners. 


\section{limited liability. ${ }^{39}$}

Thus, it is not clear that stockholders benefit to a greater extent from the corporate form than do creditors, and any difference is, in any case, only a matter of degree. ${ }^{40}$ Since bondholders, as well as shareholders, benefit from investing in a business that uses the corporate form, the reasoning in Flint suggests that bondholders' returns should be taxed in the same manner as those of shareholders. ${ }^{41}$ Accordingly, either the payment of interest on bonds should be made out of after-tax dollars or the payment of dividends should be a deductible expense for the corporation.

Despite the deficiencies of O.P.P. Holding's general standard, however, courts have used it in attempting to distinguish debt from equity. ${ }^{42}$ But because of the wide variety of instruments and transactions that have required classification as debt or equity, the courts have spawned a bewildering variety of tests and standards requiring highly fact-bound and uncertain legal determinations. One commentator counted thirty-eight different factors that had been considered by the courts in trying to classify an interest as debt or equity. ${ }^{43}$ Another stated that "[t]o look to the case law for

39 Another reason that creditors may benefit from limited liability is that potential litigation costs are reduced. If the owners were personally liable for the corporation's debts, there might be suits against the purported creditors of bankrupt corporations alleging that they were in fact owners and thus liable. As it is now, there is already significant litigation in bankruptcy over the issue of the priority of claims against the debtor. See, e.g., Costello v. Fazio, 256 F.2d 903 (9th Cir. 1958) (plaintiffs sued purported creditors of a bankrupt corporation, claiming that defendants' loans were in fact contributions to capital and that plaintiffs therefore had priority in bankruptcy). But in such cases, at least, the courts need only determine the relative priorities of the various parties' claims and can look to contractual terms, well-established equitable principles, and other factors to make these determinations. The determination would become immeasurably more complex if the courts were also required to determine absolutely whether each party was in fact an equity holder and therefore personally liable as an "owner." The concept of limited liability avoids such costly litigation by protecting owners against claims in bankruptcy.

10 This argument is further supported by the insight, discussed infra notes 70-96 and accompanying text, that both stocks and bonds are nothing more than rights to the future stream of income from a corporation's assets: if the capitalization of the corporation is irrelevant from an economic and financial point of view, owners and creditors occupy functionally indistinguishable positions as investors in the corporation. Cf. Alchian \& Demsetz, supra note 24, at $789 \mathrm{n} .14$ (creditors and shareholders are simply different classes of investors).

11 This argument assumes, as Flint did, that the reason for the corporate income tax has something to do with the benefits derived from doing business as a corporation.

12 See, e.g., United States v. Snyder Bros. Co., 367 F.2d 980, 984, 988 (5th Cir. 1966); Seaboard Realty, Inc. v. District of Columbia, 184 F.2d 269, 270 \& n.2 (D.C. Cir. 1950); see also Plumb, supra note 5, at 404-05 (referring to O.P.P. Holding as providing a "classic definition" of debt).

43 They were: formal authorization of "debt"; ascertainable principal amount; time to maturity; postponement of stated maturity; default provisions; default provisions not being 
guidance is to invite bewilderment. . . . You can find a case which supports almost any reasonable argument."44 Finally, a district court judge stated that the distinction was reminiscent of Justice Stewart's well-known "definition" of pornography. ${ }^{45}$ Consequently, the O.P.P. Holding standard has proven to be essentially empty; courts in fact engage in an ad hoc consideration of various factors, with the result that this area of the law suffers from a lack of consistency and clarity.

\section{B. The Treasury's Proposed Regulations Under Section 385}

In 1969 , Congress attempted in section $385^{46}$ to provide guidance in this area by authorizing the Secretary of the Treasury to issue regulations governing the classification of debt and equity. Despite the courts' lack of success in formulating and applying tests based on the application of various factors, section 385 invites an administrative agency to use the same method of classification. Given the courts' failure to distinguish debt from equity successfully, "it is not clear why Congress thought the Treasury could supply a clear-cut definition or why, if one is possible, Congress did not do the job itself." 47 Nevertheless, section 385 directs the Secretary of the Treasury to include in his regulations "factors which are to be taken into account in determining . . . whether a debtor-creditor relationship exists or a corporation-shareholder relationship exists," and lists several factors that "may [be] in-

invoked; specificity of interest provisions; source of interest; discretion of obligor in paying interest; "understanding" as to nonobservance of terms; cumulativeness of interest; possibility of unilateral modification; specificity of rights upon dissolution; subordination; dependency of repayment on success of business venture; identity of interest between stockholders and bondholders; nature of creditor; dependency of interest upon director action; participation of bonds in profits; creditor participation in management; package financing of the corporation; whether debt was really a conversion of equity; whether the original capital was adequate; timing of the creation of the indebtedness; thinness of capital; form of the instrument; uncertainty of obligor as to what the security is; ability of borrower to borrow from nonstockholders; creditors expectation of repayment; how the obligor carried "debt" on its books; corroborative evidence; convertibility of indebtedness; nomenclature; industry practice; whether the indebtedness was secured; existence of a sinking fund; pattern of stockholder borrowing; and intent. Holzman, The Interest-Dividend Guidelines, 47 TAXES 4 (1969).

"Hickman, The Thin Corporation: Another Look at an Old Disease, 44 Taxes 883, 885 (1966).

4s Sansberry v. United States, 25 A.F.T.R.2d (P-H) if 70-394, at 70-622 n.4 (S.D. Ind. 1970) (citing Jacobellis v. Ohio, 378 U.S. 184, 197 (1964) (Stewart, J., concurring) ("I know it when I see it . . . .")); see also Plumb, supra note 5, at 370-71 (discussing the "jungle" of conflicting decisions and criteria).

18 I.R.C. § 385 (1982).

17 B. BitTKER \& J. Eustice, supra note 15, $\pi$ 4.02, at 4-8. 
clude[d] among other factors."48

While the Treasury might have made the best of a bad situation and used the mandate provided by section 385 to fashion a simple and easily administrable set of guidelines for classifying debt and equity, it did not do so. The regulations it proposed in $1980^{49}$ did not simplify the issue, either in the arm's-length context or in the more difficult area of closely held corporations. The proposed regulations left certain key elements of the classification scheme either essentially undefined or surprisingly vague. For example, the proposed regulations assumed that the "fair market value" 50 of an instrument was determinable and that a corporation with "excessive debt" w1 was recognizable. An interest in a corporation would be "substantially proportional"s2 and a creditor "independent" 63 when "all relevant facts and circumstances" that this determination was proper. All of the above factors would certainly be the subject of complex and fact-bound litigation. The proposed regulations thus provided no better guide for evaluating these factors (and thus "distinguishing" debt from equity) than did the prior case law with its morass of "relevant" facts and circumstances.

The proposed regulations were perhaps at their weakest when they provided guidelines for the classification of hybrid instruments. An instrument would be classified as debt if its debt features accounted for more than half of its value. ${ }^{\mathrm{s}}$ According to the regulations and the examples that the Treasury appended to them,

48 I.R.C. § 385(b) (1982). Section 385(b) provides in full:

The regulations prescribed under this section shall set forth factors which are to be taken into account in determining with respect to a particular factual situation whether a debtor-creditor relationship exists or a corporation-shareholder relationship exists. The factors so set forth in the regulations may include among other factors:

(1) whether there is a written unconditional promise to pay on demand or on a specified date a sum certain in money in return for an adequate consideration in money or money's worth, and to pay a fixed rate of interest,

(2) whether there is subordination to or preference over any indebtedness of the corporation,

(3) the ratio of debt to equity of the corporation,

(4) whether there is convertibility into the stock of the corporation, and

(5) the relationship between holdings of stock in the corporation and holdings of the interest in question.

49 See supra note 9.

so Proposed Regulations, supra note $9, \S 1.385-3(\mathrm{~b})$.

s1 Id. § 1.385-6(f)(2).

${ }^{52}$ Id. $\S 1.385-6(\mathrm{a})(1)$.

${ }^{63}$ Id. $\S 1.385-6(\mathrm{~b})$.

st Id.; id. § 1.385-6(a)(2)(i).

${ }^{o}$ Id. \& 1.385-5(a). 
the debt value of an instrument meant the present value of any payments guaranteed by the terms of the instrument. ${ }^{56}$ For example, an instrument that promised to pay a large bonus if the corporation was profitable, but to pay some fixed amount even if the corporation was not, would be classified as debt so long as the fixed payments had a present value equal to at least half of the instrument's cost.

This approach is flawed from a practical viewpoint. While dividend payments on shares of stock may not technically be guaranteed, they may virtually be guaranteed by a long history of consistent payments by the company and the expectation that such payments will continue. ${ }^{57}$ Furthermore, it would not be surprising if these "guaranteed" dividend payments typically accounted for more than fifty percent of the total value of the stock. Consequently, there was little distinction between the financial attributes necessary to qualify an instrument as debt under the proposed regulations and those attributes that are often associated with ordinary equity..$^{58}$

${ }^{88} I d$. $\S 1.385-5$. More precisely, the Proposed Regulations provided that a hybrid instrument would be treated as debt unless the fair market value of the instrument without its equity features was less than $50 \%$ of its total fair market value. $I d$. $\S \S 1.385-4(\mathrm{a}),-5(\mathrm{a})$. "Equity features" was defined to exclude fixed payments, $i d$. $\S 1.385-5(b)$, (d)(1), so the debt value of a hybrid instrument was implicitly defined as the value of these fixed, or guaranteed, payments.

${ }^{67}$ There is, of course, always some chance that a payment on even a blue-chip share will not be made, and it may be important to an investor to determine whether he can afford the worst-case scenario that goes with the instrument. Every investment has the theoretical possibility of becoming worthless. But when the probability of that occurring becomes small enough it ceases to have any real meaning. Only by examining both the possible payoffs and the probabilities associated with them can an instrument be evaluated properly. Thus, even the worst-case scenario evaluation of an instrument becomes an evaluation only of the worst-case that has any significant probability of occurring. Cf. R. BREALEY \& S. MYERS, supra note 26, at 134-35 (discussing valuation and the relationship of risk and return). One of the instruments that was created to take advantage of this flaw in the proposed regulations was the adjustable rate convertible note (ARCN). Even though the minimum payment of an ARCN was, in a formal sense, now guaranteed, the likelihood of the minimum payment being made was no greater than that of a realistic worst-case scenario for many common stocks. While the addition of a formal guarantee was enough to allow the ARCNs to pass the Service's test for debt, the Service itself recognized how far removed this approach was from financial reality when it quickly acted to withdraw the Proposed Regulations after ARCNs began to appear. See supra notes 9-12 and accompanying text.

${ }^{68}$ Of course, not all firms issue stock with effectively guaranteed payments that make up more than half the stock's value. Large, publicly traded companies are most likely to issue such stock for two reasons. First, these companies are more likely than small or closely held companies to be stable and well-established, and are therefore more likely to have a history of consistent dividend payments. Second, larger companies typically employ a greater variety of financial instruments in order to appeal to a greater variety of investors, and are thus more likely to issue some stock that carries a significant "guaranteed" dividend 
Lawyers and investment bankers quickly became aware of the possibilities for taking advantage of the weaknesses in the proposed regulations. Hybrid instruments, such as adjustable rate convertible notes (ARCNs), began appearing that provided for guaranteed payments having a present value just greater than half the issue price; variable payments tied to the issuer's commonstock dividends were included and these instruments could be converted into shares of the issuer's stock. ${ }^{59}$ Such instruments provided all the essential features of ordinary equity and at the same time qualified for the same favorable tax treatment as ordinary debt. ${ }^{60}$ Issuers could thus fashion instruments that provided investors with all the benefits of stock in addition to the security of a fixed payment if the corporation's fortunes took a turn for the worse, and all at a lower after-tax cost to the firm than would have been incurred with straight equity. These benefits were effectively paid for with money that would otherwise have gone to taxes. The title of an investment banker's memorandum on the subject demonstrates the true nature of these instruments: Adjustable Rate Convertible Notes: A New Equity Financing Technique. ${ }^{61}$

In Revenue Ruling $83-98{ }^{62}$ the Service implicitly acknowledged that the proposed regulations did not properly classify the hybrid instrument (an ARCN) under review. ${ }^{63}$ The ruling stated

return. Larger, publicly traded corporations are therefore the most likely to take advantage of the Treasury's proposed regulations-or, indeed, of any regulations that condition debt treatment on an essentially arbitrary proportion of an instrument's debt features to its total value - by simply recasting their equity instruments in a way that will qualify them for debt treatment. (Ironically, the Treasury's proposed regulations were intended to "appl[y] primarily to hybrid instruments . . . issued by public corporations. Hybrid instruments issued by closely held corporations are generally treated as stock under [the proposed regulationsl." 45 Fed Reg. 18,960 (1980).) Thus, this comment's proposed solution, which is limited to large, publicly traded corporations, see infra notes 116-18 and accompanying text, focuses on that segment of the corporate population that is most likely to benefit unjustifiably from this sort of line-drawing.

39 See, e.g., Borg-Warner Corp., Prospectus (Dec. 2, 1982); Hercules, Inc., Preliminary Prospectus (Mar. 1983); Mapco, Inc., Preliminary Prospectus (Jan. 1983).

60 The holder would in effect receive a proportionate share of any entrepreneurial profits earned by the issuer, whether paid out as dividends or kept as retained earnings. The former would be accomplished by means of the variable payments, the latter by the ability of the holder to capture any appreciation due to retention of earnings by exercising his right to convert the instrument into shares of stock.

${ }^{61}$ Lehman Brothers Kuhn Loeb, Inc., Adjustable Rate Convertible Notes: A New Equity Financing Technique (Dec. 1982) (unpublished memorandum on file with The University of Chicago Law Review).

${ }^{62}$ Rev. Rul. 83-98, 1983-2 C.B. 40.

es The instruments were to have been sold for either $\$ 1000$ or 50 shares of the stock of $X$ Corporation (then trading at $\$ 20$ per share and thus worth $\$ 1000$ ). The investor was to receive annual payments equal to the dividends on 50 shares of $X$ common plus two percent 
that because the instruments were almost certain to be converted into stock and because their debt features had little "economic value or practical significance," the instruments were to be treated as equity from the outset. ${ }^{64}$ The Service subsequently withdrew the proposed regulations, ${ }^{65}$ stating that they did not "fully reflect the Treasury or IRS position on debt/equity matters."66 The Service's position in Revenue Ruling 83-98 and in the withdrawal announcement left open the possibility that it would be willing to classify some hybrid instruments as debt, despite the difficulty of drawing a line between those "debt features" that have "economic value or practical significance" and those that do not. But even if such a line could be drawn, it is unclear why corporations should be permitted to obtain the tax advantages of debt for the equity features of a hybrid instrument-features that would receive entirely different tax treatment if embodied in a separate instrument.

These flaws in the Service's approach become all the more significant in view of the fact that the "windfall" of debt treatment for equity features is the primary motivation for the creation of such instruments in the first place. Under this approach, corporations wishing to raise capital will continue to try to get as close to the line as possible so that they can enjoy the flexibility of equity financing and the tax advantages of debt. ${ }^{67}$

of the issue price ( $\$ 20)$. The annual payment was guaranteed to be at least $\$ 60$ and no more than $\$ 175$ in all years. In other words, as long as the instrument was outstanding, the investor would receive payments at a rate between $6 \%$ and $17.5 \%$ of its face value. The instrument was to be convertible at any time by its holder into 50 shares of $X$ common stock. If unconverted at the end of 20 years, the instrument was to be redeemed for $\$ 600 . X$ Corporation was to have the option to call the note for $\$ 600$ at any time more than two years after its issue. If called, however, the investor could elect instead to convert the instrument.

Although the Service did not mention its proposed regulations in the revenue ruling, the ARCN under review would have qualified for debt treatment under the regulations.

64 Rev. Rul. 83-98, 1983-2 C.B. at 41.

as 48 Fed. Reg. 31,053-54 (1983).

${ }^{68} I d$. at 31,054 , col. 3 . The withdrawal announcement did not state exactly what the Treasury's position was.

${ }^{67}$ To say that firms wish to finance with equity because it is more flexible than debt while they prefer debt because of its tax advantage is not meant to suggest that there is a real difference between debt and equity. While it may seem that the firm retains more flexibility if it has stockholders than if it has creditors, this distinction is illusory. Creditors try to ensure the maximum possible protection for their investment in advance by obtaining contractual guarantees that the firm will behave in certain ways. Equity claimants are also interested in ensuring that their investment does as well as possible, but they do so by monitoring management performance and ousting management when it does not perform satisfactorily. The firm's management is under equally severe restrictions in each case. See Easterbrook \& Fischel, Corporate Control Transactions, 91 YALE L.J. 698, 698 \& passim (1982); Easterbrook \& Fischel, The Proper Role of a Target's Management in Responding to a Tender Offer, 94 Harv. L. REv. 1161, 1165-74 (1981). 
There is no apparent reason why the Service and corporate taxpayers should continue to engage in such line-drawing and linetesting exercises. The problem of the administration of the debtequity distinction in the context of hybrid instruments would be solved if corporations wishing to enjoy the tax advantages of debt were simply required to issue straight debt without gimmicks. Whether or not this is a satisfactory result will depend on the realities or policies behind the debt-equity distinction. As has been shown, the traditional rationales for the debt-equity distinction provide little guidance in fashioning a workable test. They also appear to be based on false premises: it is hard to see that creditors benefit from the existence of the corporate form any less than stockholders, or that creditors are any less "adventurers in the corporate enterprise."68

\section{The Debt-Equity Distinction in Finance Theory and Tax PoLICY}

Part I has shown that the courts and the Treasury have failed to give meaning to the debt-equity distinction. The proffered justification for distinguishing debt from equity is based on purported differences between the shareholder-firm relationship and the bondholder-firm relationship, the shareholder being characterized as more of an "adventurer" in the corporate enterprise. ${ }^{69}$ Since the relationship between a firm and its claimants is essentially a financial one, addressed by finance theory, it may be useful to explore financial and economic considerations that might provide a principled distinction between debt and equity. An analysis of these considerations will show, however, that while such concepts are relevant in fashioning corporate tax policy, they hold out little hope of

Some investors prefer the bundle of rights represented by stock while some prefer those represented by debt. Even without the tax advantages of debt, many firms would still wish to sell some debt because certain investors prefer to own a fixed rather than a residual claim. If the tax treatment of debt and equity were reversed, and stock, rather than debt, had the tax advantage, then firms would seek the advantages to be gained by satisfying that investor clientele that prefers debt while trying to make it appear that equity was being issued in order to gain the tax advantage.

If the marketplace is efficient, firms will offer various sorts of securities up to the point where all investor groups are satisfied. Thus, no firm can raise capital more cheaply by trying to appeal to an unsatisfied clientele when the market is in equilibrium. From the point of view of the individual firm, the choice of equity or debt financing is unimportant. See Miller, Debt and Taxes, 32 J. Fin. 261, 269 (1977).

${ }^{68}$ See supra notes 34-41 and accompanying text.

Bo See supra note 22 and accompanying text. 
solving the debt-equity problem-at least within the confines of section 385 .

\section{A. Finance Theory}

The theory of corporate finance is concerned primarily with maximizing the value of the firm. In order to achieve this goal, it seeks to answer two separate but related questions. First, on what investments should the firm spend its money? Second, from what sources (for example, lenders or shareholders) should the firm raise this money? That is, what should the capital structure of the firm be if the firm wishes to raise the most money at the least cost? ${ }^{70}$ The existence of an optimal capital structure, and its theoretical and practical determinants, may provide some insight into the disparate tax treatment of corporations that contain differing proportions of debt and equity in their capital structures.

A firm seeking to raise funds for investment may choose either debt, which has been defined as a "promise to pay [from] fixed schedules of interest in the future in exchange for . . . cash now," or equity, which may be provided by existing shareholders (retained earnings) or by the sale of new shares. Besides the "pure" instruments represented by classic debt and equity, the firm may raise capital through other, less readily definable methods such as convertible debentures, preferred stock, nonvoting stock, warrants, and new hybrid instruments such as ARCNs. ${ }^{72}$

Franco Modigliani and Merton Miller performed the pioneering theoretical work in the area of capital structure. ${ }^{73}$ They proved that in an idealized world" "the market value of any firm is inde-

${ }^{70}$ Whether this second decision matters at all is a debated issue. See R. Brealey \& S. MYers, supra note 26, at 350; infra notes 71-99 and accompanying text.

71 T. Copeland \& J. Weston, Financial Theory and Corporate Policy 382 (2d ed. 1983).

72 The importance of ARCNs in precipitating the withdrawal of the Proposed Regulations, supra note 9 , under section 385 makes their inclusion in this list especially appropriate. Cf. Rev. Rul. 83-98, 1983-2 C.B. 40 (disallowing debt classification for an ARCN that would have qualified under the Proposed Regulations).

${ }^{73}$ See Modigliani \& Miller, The Cost of Capital, Corporation Finance and the Theory of Investment, 48 AM. Econ. REv. 261 (1958) [hereinafter cited as Modigliani \& Miller, Corporation Finance]; Modigliani \& Miller, Corporate Income Taxes and the Cost of Capital: A Correction, 53 Am. Econ. Rev. 433 (1963).

" Specifically, such a world is one with frictionless capital markets, where individuals can borrow and lend at the same rate as can corporations, where bankruptcy is costless, where there are only two sorts of capital-raising devices (risk-free debt and risky equity), where there are no taxes, and finally, where there is no economic growth. Modigliani \& Miller, Corporation Finance, supra note 73, at 265-68. Further analysis has shown, however, that many of these assumptions can be relaxed without affecting the result derived by Mo- 
pendent of its capital structure and is given by capitalizing its expected return at the rate . . . appropriate to its [risk] class."75 Thus, regardless of the mix of stocks and bonds issued by a firm, the combined value of all such instruments-that is, the total value of the firm-will equal the present discounted value of the firm's future cash flows. ${ }^{76}$

This conclusion is not intuitively obvious, and it seems contrary to the conventional wisdom on the gains available from socalled "leverage" or "gearing." It is true that leverage will increase the firm's expected earnings per share because the firm anticipates that the return on the assets it buys with debt will exceed the fixed costs of that debt; this excess, if it is realized, will go to the shareholders. ${ }^{78}$ It is this favorable outcome that is usually

digliani and Miller. See T. Copeland \& J. Weston, supra note 71, at 384.

${ }^{75}$ Modigliani \& Miller, Corporation Finance, supra note 73, at 268.

${ }^{76}$ While the discount rate will vary from firm to firm, it will not be affected by a firm's leverage, but only by other, external factors. See R. BREALEY \& S. MYERS, supra note 26, at 350-57.

77 See V. Brudney \& M. Chirelstein, Corporate Finance 317-415 (2d ed. 1979). "Leverage" increases when the proportion of debt in a firm's capital structure increases.

${ }^{78}$ This proposition can be illustrated with a numerical example. Suppose there is a firm with no debt and only one share of stock, which has a value of $\$ 1000$. Operating income is expected to be $\$ 150$. Because there is only one share of stock outstanding and no interest expense, earnings per share will always equal the firm's operating income. The firm wishes to issue some debt in order to increase its earnings per share without increasing its total capitalization, so it issues $\$ 500$ of bonds with an interest rate of $10 \%$, obligating the firm to pay $\$ 50$ per year in interest. If the firm uses the proceeds of the bond sale to buy back half of its one outstanding share, the total value of the firm will still be $\$ 1000$, but half will be debt and half equity. If earnings are as expected, there will be $\$ 100$ of earnings ( $\$ 150$ of operating earnings minus $\$ 50$ of fixed interest obligations) spread over the half share outstanding. Earnings per share would be $\$ 200$, resulting in an increase of $\$ 50$ attributable solely to a financial reshuffling.

One might think that the shares would therefore become more valuable. Imagine, however, what will happen as operating income falls. Before any debt is added to the firm's capital structure, earnings per share will be reduced by one dollar for each dollar reduction in the firm's operating income. But with the addition of debt in the capital structure, earnings per share will be reduced by two dollars for each dollar reduction in operating income, because any such decline must be spread over only one-half share outstanding. In this example, earnings per share will be the same in both the leveraged and unleveraged cases only when operating income equals $\$ 100$ (earnings per share is $\$ 100$ in both cases). If income rises above $\$ 100$, earnings per share will be higher with leverage, but if income falls below $\$ 100$, earnings per share will be higher without leverage. With a capital structure that is $50 \%$ debt and $50 \%$ equity, for each increase or decrease in operating income of one dollar, earnings per share will correspondingly increase or decrease by two dollars.

Modigliani and Miller proved that in fact the two effects on earnings per share resulting from increasing the amount of debt in a firm's capital structure (the enhanced "upside" and the enhanced "downside") cancel each other out, and the value of the shares will be equal regardless of the amount of leverage. They did this through a so-called "arbitrage pricing model." See Modigliani \& Miller, Corporation Finance, supra note 73, at 269-71. Imagine that $A$ has a choice of investing in the hypothetical company above in either its leveraged or 
hoped for when a firm decides to issue debt. ${ }^{79}$ Since most firms expect to service comfortably any debt they might issue, they look at the possible benefits to be gained by leveraging only under the assumption that earnings will be sufficient to cover the debt; this assumption results in an expected increase in earnings available for shareholders. But the enhanced "upside" is in fact matched by an enhanced "downside": if operating income falls below a certain amount, the firm's earnings per share will be less than they would have been without debt. ${ }^{\mathbf{8}}$ Moreover, the greater the firm's leverage, the greater will be the decrease in earnings per share for any given decrease in operating income. ${ }^{81}$ Thus, while the issuance of debt increases the firm's expected earnings per share, this benefit is exactly offset by the change in the rate at which the firm's earnings are capitalized. ${ }^{\mathbf{2}}$ The net result is that a change in the firm's capital structure will not affect the firm's value.

Modigliani and Miller's argument is powerful and elegant, but it is not without its problems. Probably the most powerful general criticism of the theory is that it fails to explain observable distinctions between different industries. ${ }^{83}$ If the choice of capital structure does not affect the value of the firm, one would expect that

unleveraged states. If the leveraged half-share were for some reason more expensive than a half-share in the unleveraged firm, $A$ could borrow money at $10 \%$ (the same rate of interest at which the company can borrow funds) and buy one full share in the unleveraged company-half the share would be purchased with the borrowed money, and the other half would represent $A$ 's "equity" investment. Every dollar of earnings that the company made would result in two dollars of earnings on $A$ 's "equity" investment, and every dollar's drop in earnings would result in a two dollar drop in earnings on $A$ 's equity. As long as earnings are at least twice $A$ 's interest cost, earnings per share of "equity" will be higher in the leveraged case. This is exactly the same result that $A$ would achieve by owning the leveraged half-share. Because anyone could do this, no one would ever pay more for shares in the leveraged company. The converse is also true and can be proved by a similar argument. The argument depends on the assumption that there is a perfect capital market. That is, $A$ must be able to borrow at the same interest rate as the corporation if he is to be able to create effective "home-made" leverage. For a discussion of this aspect of finance theory, see $R$. Brealey \& S. MYers, supra note 26, at 350-60.

79 It may seem odd that firms do not consider the Modigliani-Miller thesis, which shows that the increased returns with leverage when things go well are matched by decreased returns when things do not go well. This has been attributed to the fact that the "traditional" position was that leverage did increase returns, and popular wisdom has not caught up with finance theory. Cf. R. BREALEY \& S. MYers, supra note 26, at 350-69 (discussing Modigliani-Miller and the "traditional" position).

${ }^{80}$ See supra note 78.

s1 See R. Brealey \& S. MYers, supra note 26, at 358-60; supra note 78.

${ }^{82}$ See R. BREALEY \& S. MYErs, supra note 26, at 358-60. Capitalization of earnings refers to the relationship between a change in earnings and the change in earnings allocable to equity capital.

${ }^{83}$ See T. Copeland \& J. Weston, supra note 71, at 440-41, 453-59. 
the debt-equity ratio would vary randomly among firms both within the same industry and in different industries. In reality, however, each industry tends to have a characteristic debt-equity ratio. ${ }^{84}$

It is surprisingly difficult to identify specific reasons why the Modigliani-Miller model does not correspond to empirical observation. The root of the problem would seem to lie in the assumptions upon which the model apparently depends, which do not hold true in the real world. ${ }^{85}$ For example, the Modigliani-Miller analysis ignores taxes, ${ }^{86}$ though a real firm's capital structure obviously will affect the value of the firm by affecting the amount of taxes that it must pay. As the firm increases the amount of debt that it carries, an increasing proportion of its earnings must go to creditors in the form of interest payments. Because such payments are deductible from earnings in computing taxable income, while comparable payments on equity (i.e., dividends) are not, ${ }^{87}$ the increased debt will result in tax savings, and the firm's cost of capital will fall.

Once tax effects are incorporated into the Modigliani-Miller model, it might appear that firms should move toward a capital structure that is nearly all debt. ${ }^{88}$ But the existence of different debt-equity ratios among firms in different industries-indeed, many firms carry little or no debt at all-indicates that an all-debt capital structure is not in fact optimal. If the basic ModiglianiMiller model is correct, there must be other factors at work in the real world that can explain why firms do not adopt an all-debt capital structure.

It has been suggested that the existence of positive costs of bankruptcy explains why an all-debt capital structure is not even theoretically desirable. ${ }^{89}$ The expected cost of bankruptcy will in-

B4 See R. Brealey \& S. Myers, supra note 26, at 373.

${ }^{85}$ See supra note 74 and accompanying text; T. Copeland \& J. Weston, supra note 71, at 384.

8s See supra note 74 and accompanying text.

${ }^{87}$ See supra notes $14-15$ and accompanying text.

ss From a legal and financial standpoint, it would be impossible for a firm to move to an all-debt capital structure. If a firm is financed entirely by debt, then it is almost insolvent by definition. See 11 U.S.C. \& 101(26) (1982) ("insolvency" occurs when the value of the debtor's liabilities exceeds the value of the debtor's assets). If a firm is $100 \%$ debt $\mathrm{fi}$ nanced, its common stock would be valueless (or else it would not be $100 \%$ debt financed). Since there could be no residual earnings after payment of fixed claims (otherwise the stock would have value), it is highly unlikely that even the fixed claims could be entirely satisfied.

If the firm is bankrupt, then the creditors will become its new owmers and it will be $100 \%$ equity financed again. That is, the old creditors will take an equity interest in the firm and the old shareholders will be squeezed out.

80 Baxter, Leverage, Risk of Ruin and the Cost of Capital, 22 J. Fin. 395, 396-98 (1967). 
crease as the firm takes on more debt because the firm is more likely to go bankrupt as its fixed obligations increase. A firm's optimal debt-equity ratio would be the point at which the marginal decrease in the cost of capital resulting from the addition of debt equals the marginal increase in the expected cost of bankruptcy. If the expected cost of bankruptcy is relatively trivial, however-and it seems that it is ${ }^{90}$ - this argument does not explain observed deviations from an all-debt capital structure. ${ }^{91}$

Moreover, Merton Miller has shown that the ModiglianiMiller hypothesis remains intact once the personal income tax is taken into account in addition to the corporate tax. ${ }^{.2}$ While payments on debt are deductible at the corporate level, debtholders are taxed more heavily than equityholders at the individual level because much of the return on equity may be unrealized capital gains that will not be taxed for years to come, ${ }^{93}$ while interest pay-

Bankruptcy costs include attorneys' fees, trustees' fees, and the costs of low liquidity during reorganization. Id.

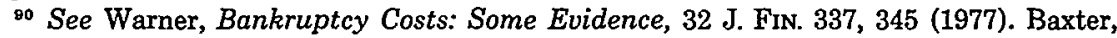
supra note 89 , found bankruptcy costs to be significant, so his results may appear to contradict Warner's results. Closer inspection, however, reveals that Baxter's study dealt mainly with bankruptcies of individuals and small businesses, mostly proprietorships, undergoing liquidation rather than reorganization. See Baxter, supra note 89, at 396-98; see also Miller, supra note 67, at 262 (discussing Baxter's study). Warner's study, on the other hand, focused on large, publicly held corporations. See Warner, supra, at 338; see also Miller, supra note 67, at 262-63 (discussing Warner's study). Consequently, the bankruptcy-cost argument for an optimal capital structure applies, if at all, only to small, closely held corporations, while this comment's proposed solution applies only to large, publicly held corporations. See infra notes 116-18 and accompanying text.

81 Another argument for the existence of an optimal debt-equity mix is based upon the problem of agency costs. As a firm uses more debt to finance its investments, creditors prefer safer investments that are likely to cover the higher level of fixed obligations, while owners prefer riskier (i.e., larger potential gains, but greater chance of loss) investments since there is now less equity to be lost. Consequently, the gap between the interests of the firm's owners and those of its creditors widens. See Gordon, Towards a Theory of Financial Distress, 26 J. FIN. 347 (1971); Jensen \& Meckling, Theory of the Firm: Managerial Behavior, Agency Costs and Ownership Structure, 3 J. Fin. Econ. 305 (1976); Myers, Determinants of Corporate Borrowing, 5 J. Fin. Econ. 146 (1975). When this occurs, the creditors must incur monitoring costs-for example, the costs of writing and enforcing bond covenants-to ensure that their interests are not slighted by the shareholders. The optimal debtequity mix would be the point where the marginal increase in agency costs from an increase in debt is equal to the marginal decrease in the cost of capital. External equity, however, carries its own agency costs, such as the monitoring of corporate directors. The agency-cost theory of an optimal debt-equity ratio is thus unhelpful in explaining why firms would choose between differing proportions of debt and equity in designing their capital structures. See T. Copeland \& J. WeSton, supra note 71, at 446, and sources cited therein.

${ }^{92}$ Miller, supra note 67, at 267-71.

${ }^{93}$ Id. at 270. Professor Miller points out that the effective marginal tax rate on income from shares may even be close to zero since taxes on capital gains can be deferred at the option of the holder, and "by conventional folk wisdom, 10 years of tax deferral is almost as 
ments are taxed immediately as ordinary income. ${ }^{94}$ There is an equilibrium debt-equity ratio for the corporate sector as a whole that depends upon the corporate tax rate and the individual tax rates of all the various investors; ${ }^{95}$ each firm adopts a particular capital structure in order to appeal to a particular class of investor that is seeking investments with a particular tax characteristic. Miller argues, however, that there is no optimal capital structure for any given firm and that it is still true "that the value of any firm, in equilibrium, [is] independent of its capital structure, despite the deductibility of interest payments in computing corporate income taxes."

Even if the deductibility of interest payments supported an argument that there is an optimal debt-equity ratio, however, such an explanation would depend on the existing tax system and would therefore provide no guidance in fashioning tax policy itself.

\section{B. Implications for Tax Policy}

Although current finance theory does not support a principled distinction between debt and equity, it would be inappropriate to argue that the tax law should in fact treat debt and equity identically, unless one were also to argue for the abolition of the corporate income tax itself. ${ }^{97}$ Congress has required that a distinction be drawn between debt and equity, and a workable solution to the debt-equity problem must be found within the confines of current tax law-and specifically within section 385 . Furthermore, the theoretical conclusion that there is no optimal capital structure is contradicted by the powerful empirical observation that various industries in fact tend to have characteristic debt-equity ratios. ${ }^{98}$

The theory of corporate finance is, however, relevant in a negative way to the formulation of tax policy within the context of section 385. Although some distinction must be made between debt and equity, Congress has established no presumption in favor of any particular distinction. Consequently, if a particular line is to

good as exemption." Id. In addition, those stocks that pay high dividends (where the return is thus mostly ordinary income and cannot be deferred) will be preferred by tax-exempt organizations and low-income investors. Id. at 269-70.

94 I.R.C. $\$ \S 61(\mathrm{a})(4), 63(\mathrm{~b})$ (1982).

os Miller, supra note 67 , at 270 . For example, tax-exempt and low-income investors prefer interests that produce immediate ordinary income, while those in high tax brackets prefer interests that result in deferred capital gain. Id. at 269-70.

98 Id. at 269.

97 See supra note 19 and accompanying text.

98 See supra notes 83-84 and accompanying text. 
be drawn it must be justified on other grounds. A rational basis for drawing a particular distinction between debt and equity is especially important where the proposed distinction is difficult or costly to apply - time and effort should not be expended without a good reason for doing so. The theory of corporate finance seems an appropriate place to look for a distinction between debt and equity upon which tax policy can be based. If the Modigliani-Miller model is correct, however, and if it therefore does not matter from the financial viewpoint how a firm raises capital, then the theory of corporate finance does not support a principled distinction between debt and equity for tax purposes.

Nor does the Modigliani-Miller model aid in classifying an interest or obligation as either debt or equity. Even if there is an explanation for the existence of an optimal capital structure, none of the explanations that have been offered reveals why firms with different capital structures should be taxed differently. And if firms' capital structures are based upon the way particular instruments are treated for tax purposes, ${ }^{99}$ those same capital structures cannot be used as a basis for deciding how to tax payments under those instruments. In light of the evidence provided so far, the rationale, if any, for the system of deductions under the corporate income tax thus appears to be unrelated to the financial nature of corporations.

Tax practitioners, too, have understood intuitively that debt and equity are essentially indistinguishable. This notion is implicit in William Plumb's assertion that the validity of the distinction between debt and equity depends on

whether the tax laws should discriminate against equity capital . . . or whether the tax laws should be as neutral as possible in their effect upon such business judgments; and ... . whether an equitable and efficient tax system can longer tolerate a self-selected tax burden, permitting a taxpayer, by exercising his admittedly free right to choose a capital structure, to determine for himself how large a tax shall be borne for the privilege of doing business in corporate form. ${ }^{100}$

99 Several of the explanations for an optimal capital structure set out above, see supra notes 85-96 and accompanying text, rely on the existing tax system for their explanatory value. Miller's clientele argument, for example, relies on the fact that the tax system itself creates different investor clienteles. See supra notes 92-96 and accompanying text. Indeed, one of the major reasons for having debt in the first place is that it decreases the cost of capital as a result of the tax deductibility of interest payments. See supra notes $86-87$ and accompanying text.

${ }^{100}$ Plumb, supra note 5, at 620-21 (footnote omitted). 
Plumb concluded that "it is time for Congress to reexamine the purposes, if any, served by distinguishing debt from equity and, to the extent that it is possible, to bring that fruitless exercise to an end."101

Plumb's concern is connected with a larger problem in tax policy. Whenever a taxpayer manages to reduce his taxes by entering into a particular transaction, the Service and the courts will scrutinize the transaction closely to see if anything of substance was done or if, on the contrary, the taxpayer acted solely to lower his taxes. ${ }^{102}$ Although it is a well-accepted principle that it is entirely legal to arrange one's affairs in such a way as to minimize taxes, ${ }^{103}$ suspicion arises when taxpayers enter into transactions that would be irrational absent a tax savings. When two similarly or identically situated taxpayers pay vastly different taxes solely because one taxpayer has employed more clever tax counsel, the system appears unfair. Our tax system is intended to "insure that the same tax consequences result from the different types of transactions which are available to accomplish substantially the same result[s]"; ${ }^{104}$ consequently, the system's integrity is undermined

${ }^{101} I d$. at 620 . Critics of the corporate income tax rely on the undesirability of the debtequity distinction as a reason for abolishing the tax altogether, though not solely because the distinction is inherently unworkable. They argue that double-taxation of corporate income-once at the corporate level and again when it is distributed to shareholders in the form of dividends-is inefficient because it diverts investment from corporations to less efficient noncorporate entities. Corporate entities must earn a higher pre-tax return in order to offer investors an effective (i.e., after-tax) return that is sufficiently attractive to compete with noncorporate investment opportunities. This results in a nonoptimal allocation of capital and thus in a dead-weight loss to society. See, e.g., G. BreaK \& J. Pechman, Federal TAX Reform 91-97 (1975); Feldstein \& Frisch, Corporate Tax Integration: The Estimated Effects on Capital Accumulation and Tax Distribution of Two Integral Proposals, 30 NAT'L TAX J. 37, 38 (1977).

102 For example, in Goldstein v. Commissioner, 364 F.2d 734 (2d Cir. 1966), cert. denied, 385 U.S. 1005 (1967), a taxpayer was denied the tax advantages claimed for a transaction designed to produce useful deductions but incapable of being a money-maker on its own. The court found that such transactions could "not with reason be said to have purpose, substance, or utility apart from their anticipated tax consequences." Id. at 740 . The court in Rice's Toyota World, Inc. v. Commissioner, 81 T.C. 184, 209-10 (1983), found that, absent a reasonable expectation of economic profit, it was proper to disallow the tax benefits of a transaction. See also Knetsch v. United States, 364 U.S. 361, 364 (1960) (where there is " 'no commercial economic substance to the . . transaction" " it will be disregarded) (quoting trial court below); Commissioner v. Court Holding Co., 324 U.S. 331, 334 (1945) (the "incidence of taxation depends upon the substance of a transaction"); cf. Isenbergh, supra note 19 (comparing the advantages of a more formalistic tax system with those of our own, which is more devoted to discovering the "truth" about transactions).

${ }^{103}$ See Gregory v. Helvering, 293 U.S. 465, 469 (1935) ("The legal right of a taxpayer to decrease the amount of what otherwise would be his taxes, or altogether avoid them, by means which the law permits, cannot be doubted.").

${ }^{104}$ H.R. Rep. No. 1337, 83d Cong., 2d Sess. 39 (1954). 
when similarly situated taxpayers bear very different tax burdens. If the corporate counsel who designs instruments that the Service will permit to be classified as debt is only changing the form of the corporation's capital structure and not its substance, then Congress or the Treasury should act to foreclose the maneuver. ${ }^{105}$

\section{A Proposed Approach Under Section 385}

Enormous amounts of money are at stake in the classification of instruments as debt or equity, as is amply demonstrated by the hard-fought litigation over disputed instruments in general ${ }^{106}$ and by the recent experience with adjustable rate convertible notes ${ }^{107}$ in particular. Accordingly, the market will always respond with new instruments to take advantage of any line drawn by the Service. Such a response tends to be especially strong from large, publicly held corporations that constantly raise new capital, employing professional advisors to aid them in doing so. Investment bankers and tax lawyers monitor the latest tax regulations and develop instruments having the desired tax and financial characteristics, thus obtaining large tax savings for their clients. As a result, those corporations that invest in intensive tax planning enjoy an advantage over those that do not. Society has no interest in rewarding clever tax planners who effectively circumvent the tax laws. ${ }^{108}$ On the contrary, giving effect to tax planning that is all form and no substance undercuts the very foundation of our tax system ${ }^{109}$ and discourages innovation in more substantive areas. The Treasury should prevent this sort of unproductive tax planning, and section 385 provides a mechanism for doing so.

Although debt and equity are in essence indistinguishable, the

${ }^{105}$ The fact that courts have not always waited for Congress to prevent such potential inequities, but have often stepped in to prevent them on their own, has probably added to the confusion surrounding the debt-equity distinction. See Isenbergh, supra note 19, at 88182 \& passim.

${ }^{106}$ See B. BitTker \& J. Eustice, supra note $15, \pi 4.02$.

${ }_{107}$ See supra notes 59-66 and accompanying text.

${ }^{108}$ Since the corporate income tax produces inefficiencies in the allocation of resources, see supra note 101, it might be argued that such tax planners provide a benefit to society by reducing the amount of taxes paid and therefore the extent of the inefficiency. We are, however, committed to a corporate income tax, and it should be enforced in the way Congress intended.

${ }^{109}$ See Isenbergh, supra note 19 (arguing that the foundations of our tax system are being preserved at the cost of astounding complexity in the law); supra notes 102-05 and accompanying text; cf. H.R. REP. No. 1337, 83d Cong., 2d Sess. 39 (1954) (policy goal to require "that the same tax consequences result from the different types of transactions which are available to accomplish substantially the same result"). 
structure of the present corporate income tax depends on a distinction being drawn between the tax treatment of debt and equity. ${ }^{110}$ The Service has decided that the only way to enforce the distinction in the context of hybrid instruments is to characterize such instruments as either all debt or all equity for tax purposes. ${ }^{111}$ Yet to allow any such instruments to be treated as all debt only provides an opportunity for the sophisticated taxpayer to gain a windfall through the deductibility of payments made on the equity portion of the instrument.

A better approach to the debt-equity problem would be to use the authority of section 385 to set up a very simple test that any instrument would have to meet in order to be treated as debt. The most easily administrable test for debt would be the classic one: only instruments that are written and unconditional promises to pay a sum (or sums) certain in money on demand or on a specified date (or dates) would be classified as debt."12 "Sum certain" could be defined to include amounts expressed in current dollars (as opposed to nominal future payments) as long as any inflator used is external to the company. ${ }^{113}$ No other instruments would qualify for debt treatment. ${ }^{114}$ The proposed test would not be a safe harbor; rather it would be the sole test by which an instrument could be classified as debt. ${ }^{115}$ Under this test, it would be

110 If payments to holders of both debt and equity were deductible, the corporate income tax would effectively be abolished by being reduced to a tax solely on retained earnings. See supra note 19 and accompanying text. Allowing deduction of payments under neither debt nor equity would require the elimination of a longstanding element of tax policy-that interest payments should be deductible as an ordinary and necessary cost of doing business. See supra note 23 and accompanying text. Thus, either of these solutions would entail dramatic changes in the structure of the corporate income tax.

112 See supra notes 49-56 and accompanying text.

112 This test is a standard description of so-called straight debt. See Plumb, supra note 5 , at 404 .

113 The Treasury could retain the authority to designate indices that might be used for this purpose. One can imagine that questions might arise as to what indices are really external to a company. Consider, for example, the case of a silver-mining company that issues bonds whose payments are tied to the market price of silver. While the company will prosper if the price of silver goes up, the index is not necessarily an internal one. This case would present a close question that could nevertheless be dealt with by the Service through its normal administrative machinery.

${ }^{114}$ The test proposed here, see supra text accompanying note 112, is essentially equivalent to what is set out in I.R.C. $\S 385(b)(1)$ (1982) as one factor that might be considered in drafting regulations. See supra note 48 . Here the possibility of variable rates of return, tied not to the company's fortunes, but to an external index, is added.

${ }^{113}$ I.R.C. $\S 385(a)$ (1982) specifically provides that the "Secretary is authorized to prescribe . . . regulations . . to determine whether an interest in a corporation is . . stock or indebtedness." While this language might lend itself to the creation of a safe-harbor, it does not preclude the promulgation of an absolute rule. Cf. I.R.C. $\$ 367(\mathrm{~b})(1982)$ and the regula- 
pointless for a taxpayer to contest the Service's classification of an instrument: application of the test would leave little room for dispute.

This test could effectively be applied only to large, publicly held corporations. In the case of small and closely held corporations, use of this test would be impracticable because of problems unique to that context. ${ }^{116}$ Many of the problems encountered in trying to sort out what is debt and what is equity in the context of closely held corporations are essentially evidentiary ones, ${ }^{117}$ for the Service must first determine the substance of the transaction. For one example of the difficult problem of classification faced by the Service and the courts in this context, consider a controlling shareholder who advances money to the corporation and calls it a debt. If repayment on schedule seems inopportune, the shareholder might not demand payment, in which case the advance loses its debt-like character and becomes a contribution to capital.

Publicly traded instruments present a sharply contrasting situation. The terms and conditions of instruments that are registered with the Securities and Exchange Commission are easily determined. Instruments traded on stock exchanges can be bought by the public, and one can be confident that their terms will be enforced by disinterested investors. The debt-equity transformation described above for a closely held corporation could not occur in an arm's-length transaction without a formal process of negotiation and restructuring-an event that the Service would have little difficulty detecting. The reality behind a transaction (both when a registered instrument is offered and during the course of its life) can, in all but the most exceptional cases, be determined by reading the prospectus and other documents filed with the SEC.

The proposed test could therefore be promulgated by the

tions promulgated thereunder (where the Service did promulgate an absolute rule in a section dealing with reorganizations involving foreign corporations). The legislative history of section 385 itself states that "the Secretary of the Treasury is not to be bound or limited by the specific rules which the [Senate] Committee amendments and the House bill provide for distinguishing debt from equity in the corporate acquisition context." S. REP. No. 552, 91st Cong., 1st Sess. 138-39 (1969), reprinted in 1969 U.S. CodE ConG. \& AD. NEws 2027, 2170.

${ }^{116}$ Cf. Plumb, supra note 5, at 404-555 (discussing difficulty of classification where the nature of the transaction is difficult to discern-as it often is in the non-arm's-length situation of closely held corporations).

${ }^{117}$ Id. Plumb notes that for closely held corporations, the evidentiary inquiry is so difficult and the welter of considerations invoked by the courts in their search for the truth so great that the key distinction between factum probandum and factum probans has been obscured. Id. at 410 . Whether the problem of distinguishing debt and equity in this context is soluble (and if so in what manner) is beyond the scope of this comment. 
Treasury under section 385 to apply only to those instruments issued in arm's-length transactions by firms required to report to the SEC upon the issuance of the instrument. Limiting the scope of the test would also aid in its administration. Since the test would apply only to instruments required to be registered with the SEC, there would be few questions about whether it should apply to a given instrument or transaction. ${ }^{118}$

Hybrid instruments would not be classified as debt under this test because they include conditional equity features. Large, publicly held corporations would thus be unable to deduct payments made pursuant to hybrid instruments, and the cost of using these instruments to attract capital would be increased. These corporations would be forced to use straight debt instead of hybrid instruments if they wished payments to remain deductible, and to use hybrid instruments only when there are independent (non-tax) reasons for their use.

It might be argued that such a change in tax policy would discourage corporate investment projects, thus increasing the disincentive that double taxation already creates to investing in corporations. ${ }^{11}$ Such an argument, however, is not a sufficient reason to condemn the proposed rule. Any alternative rule that allows hybrid instruments to be classified as debt allows the income on projects financed by such investments to escape the regime of dual taxation inherent in the corporate income tax. While critics of the corporate income tax may find such a result desirable, there is no indication that Congress intended that section 385 be the vehicle for such fundamental tax reform. ${ }^{120}$

118 The suggestion that the Service use the registration provisions of the Securities Exchange Act of 1934, $\S \S 1-30,15$ U.S.C. $\S \S 78 \mathrm{a}-\mathrm{hh}$ (1982), as a guide in determining what transactions are at arm's length, and thus covered by the proposed test, is only a tentative one. The Securities Exchange Act and the SEC's reporting requirements have developed into quite a hodge-podge over the last 50 years, and certain anomalous exemptions from reporting exist, such as those involving insurance companies and banks. See Securities Exchange Act of $1934, \S \S 3(\mathrm{a})(12), 12(\mathrm{~g})(2)(\mathrm{G}), 12(\mathrm{~h}), 15$ U.S.C. $\S \S 78 \mathrm{c}(\mathrm{a})(12), 78 l(\mathrm{~g})(2)(\mathrm{G})$, $78 l(h)$ (1982). The rule proposed in this comment should apply to instruments exempted from SEC registration that nevertheless are required to be registered with another regulatory body (e.g., the Comptroller of the Currency for banks). See generally Lours Loss, FunDAMENTALS of Securities Regulation 459-87 (1983) (discussing the reporting requirements of the Securities Exchange Act of 1934).

110 See supra note 101.

120 If the Treasury were to use section 385 for such a reform, it might amount to an abuse of agency discretion. See Mourning v. Family Publications Serv., Inc., 411 U.S. 356, 369 (1973) ("[T] he validity of a regulation promulgated [under statutory authority] will be sustained so long as it is "reasonably related to the purposes of the enabling legislation." ") (quoting Thorpe v. Housing Auth., 393 U.S. 268, 280-81 (1969)). 
Moreover, the proposed test may not seriously discourage investment projects. If a corporation thinks it can raise money most effectively by issuing hybrid instruments, then it will be free to do so. It would also be possible for corporations to obtain the favorable tax treatment of debt for the debt features of such instruments. Instead of issuing an undifferentiated bundle of rights in a hybrid instrument, a corporation could sell a package of instruments consisting of debt, equity, and options that together would have the same financial characteristics as the desired hybrid. As long as the components could be sold separately, the Service could then treat the debt components as debt and the equity components as equity. Thus, the proposed test would not require that all hybrids be treated as equity; rather, it would merely shift the burden of unscrambling the hybrid onto its issuer. ${ }^{121}$

This bright-line test might be criticized for placing administrative convenience above all other considerations in enforcing the debt-equity distinction. If financial theory were to disclose that debt and equity are distinguishable in some fundamental way, then it would be entirely appropriate to use section 385 to implement another test based on such a distinction. ${ }^{122}$ But if the only financial distinction between debt and equity is one created by the tax system itself-as may be the case ${ }^{123}$ - then no test can be based on a truly principled analysis.

By employing this straightforward approach, the goals Congress had in mind when it authorized regulations under section 385 could be met, and with the fewest complications and confusions. The proposed test would simplify the administration of the debtequity distinction without sacrificing the kind of flexible financing now available with hybrid instruments. Not only would the pro-

121 That is, any hybrid instrument that would currently be sold as an indivisible bundle of rights could also be created as a hybrid package of separately tradeable units. From a financial viewpoint, these approaches are identical. Of course, investment projects would still be "discouraged" in a sense because corporations could no longer raise capital as cheaply as they could under the Service's current approach. Without the windfall of debt treatment for the equity features of hybrid instruments, projects that would be marginally profitable if financed by hybrid instruments under the Treasury's withdrawn regulations would become unprofitable under the approach suggested here. Such disincentives are, however, inevitable under any corporate income tax. See supra note 101. As long as Congress, by its decision to retain a corporate income tax, considers such disincentives to be justifiable, they should be strictly enforced. To the extent that corporations can avoid these disincentives by financing projects with hybrid instruments that are treated fully as debt, the corporate income tax is evaded.

${ }_{122}$ I.R.C. $\S 385(\mathrm{~b})$ (1982) permits the Treasury to consider "other factors" in addition to those specified.

${ }^{123}$ See supra notes 70-105 and accompanying text. 
posed test permit the Service to tax hybrids on a proportional basis-something that the withdrawn regulations with their all-ornothing approach failed to do-it would also relieve the Service of the impossible task of unscrambling the components of instruments whose values depend on future possibilities that are unknowable and that the market is better able than the Service's staff to estimate.

A final objection to the proposed test is that it might constitute an abuse of the discretion delegated to the Treasury under section 385. One might argue that the test is in effect only the first of five factors that section 385 directs "may [be] include[d] among other factors," 124 and that Congress therefore intended a more complex test reflecting, presumably, a more complex reality. The proposed test, however, would only be applicable in the arm'slength context-only one among a number of the contexts in which the debt-equity distinction is important. The Treasury would thus remain free to consider applying all the factors listed in section 385(b), as well as others not listed, in such other contexts as small and closely held corporations. Accordingly, the other provisions of the statute would not be rendered meaningless by the proposed test; they would be reserved for use in other regulations to be promulgated under section 385 . It is conceivable, for example, that a modified version of the proposed regulations that were withdrawn by the Treasury ${ }^{125}$ would be acceptable when applied in non-arm's-length situations. ${ }^{126}$

\section{CONCLUSION}

The problem of classifying payments under various instruments for the purpose of defining a corporation's income is almost as old as the corporate income tax itself. It is an inescapable dilemma created by the facts that some class of payments by corporations must remain subject to corporate-level taxation in order for the tax to have any meaning, and that there is no principled basis for distinguishing between various classes of payments for this purpose. This comment has shown that, at least in the context of

124 I.R.C. $\$ 385$ (b) (1982). The five factors are quoted supra note 48.

${ }^{125}$ Proposed Regulations, supra note 9.

126 Some modifications would have to be made to prevent the use of such instruments as ARCNs in closely held corporations. Special loophole-closing provisions could probably be added to accomplish this purpose. Such regulations would necessarily be more difficult to administer than those proposed by this comment for the arm's-length situation, but, as noted above, see supra notes $116-18$ and accompanying text, the solution proposed in this comment is unsuited for the non-arm's-length situation. 
arm's-length transactions, it would be best simply to cut the Gordian Knot. The Treasury should use its authority under section 385 to adopt a strict rule allowing deductions for payments by large, publicly held corporations only when they are made under instruments that closely resemble "true" debt. By adopting such a rule, many of the problems of administering the debt-equity distinction would be alleviated, and the need to draw problematic lines that only encourage wasteful and inequitable tax planning on the part of issuers would be eliminated. At the same time, issuers would remain free to employ hybrid instruments so long as they took responsibility for differentiating their components.

Adam O. Emmerich 